\title{
Effect of Ringing and Incision Given to the Stem on the Transmission of Photoperiodic Stimulus in Pharbitis Nil
}

\author{
Shun-ichiro ImamURA* and Atsushi TaKimoto* \\ 今村駿一郎*・滝本＼cjkstart敦*：アサガオの日長刺激伝達に及ぼす荠の輪截及び切込の影響
}

Received August 29, 1956

It has been reported in Xanthium and Perilla that the transmission of photoperiodic stimulus is inhibited by girdling or ringing given to the stem between the donor leaf and the receptor bud $(1,2,6)$. From this fact, besides others, it appeared probable that the phloem was the tissue of transmission of photoperiodic stimulus. Therefore it was desirable to get more information on the effect of ringing and incisions upon the flowering response in other plants. The present paper deals with experiments regarding this point with Pharbitis Nil. The material used was the same as in previous papers $(3,4)$.

Transmission across the ringed stem. When the plants grown under continuous illumination developed three fully expanded leaves, the main axes were removed above the third node. The cotyledons and the first leaf, and their axillary buds, were removed. The stem between the second and third leaf was ringed, and then one of the leaves was given 8 hour short day treatment for three days by use of light-proof bags, while the other leaf was left exposed to continuous illumination.

Ringing was done by constantan wire which was looped around the stem and heated by electric current. By this operation all the living cells in the operated zone are killed, and after a day or so they change their color to brown, but the vessels of the stem continue to function normally or apparently so, supplying water to the upper portion of the stem and thus enable the upper part to remain alive and to develop axillary buds. After about ten days, however, gradually the buds begin to wilt. Control plants were not ringed and the second or third leaf was given short day treatments in the same manner as in the experimental lot. The light control lot was continuously exposed to light. About ten days after the treatment, the third node of the ringed plants was cut off and its lateral shoot which showed an indication of wilting was examined. After further ten days or so the third lateral shoot of control plants was examined, and the third node was removed

* Laboratory of Applied Botany, Faculty of Agriculture, Kyoto University. 京都大学農学部 応用植物学研究室 
to force the axillary bud of the second node to develop. Flower initiation on the second lateral shoot in both experimental and control lots was examined about two weeks after the removal of the third node. The experiments were several times repeated and all showed similar results. The results of one experiment are shown in Table 1. All plants without ringing initiated flower primordia on the lateral

Table 1. Transmission of photoperiodic stimulus across the ringed stem of Pharbitis Nil.

(Sown on May 25, treatment started on July 2, 1951)

\begin{tabular}{|c|c|c|c|c|c|c|c|c|}
\hline \multirow[t]{2}{*}{ Treatment } & \multirow{2}{*}{$\begin{array}{l}\text { Leaf ex- } \\
\text { posed to } \\
\text { short } \\
\text { days }\end{array}$} & \multirow[t]{2}{*}{$\begin{array}{c}\text { No. of } \\
\text { plants } \\
\text { observ- } \\
\text { ed }\end{array}$} & \multicolumn{2}{|c|}{$\begin{array}{l}\text { No. of plants with } \\
\text { flower primordia } \\
\text { on axillary shoot } \\
\text { of the }\end{array}$} & \multicolumn{2}{|c|}{$\begin{array}{l}\text { No. of flower pri- } \\
\text { mordia on axillary } \\
\text { shoot of the }\end{array}$} & \multicolumn{2}{|c|}{$\begin{array}{c}\text { Average number of } \\
\text { flower primordia } \\
\text { per plant }\end{array}$} \\
\hline & & & 2nd node & 3rd node & 2nd node & 3rd node & 2nd node & 3rd node \\
\hline $\begin{array}{l}\text { Stems be- } \\
\text { tween 2nd } \\
\text { and 3rd }\end{array}$ & 2nd leaf & 50 & 47 & $0 *$ & 272 & 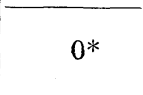 & $5.5 \pm 0.30$ & $0^{*}$ \\
\hline $\begin{array}{c}\text { nodes were } \\
\text { ringed }\end{array}$ & 3rd leaf & 50 & 0 & $48^{*}$ & 0 & $160^{*}$ & 0 & $3.2 \pm 0.18^{*}$ \\
\hline \multirow{3}{*}{ No ringing } & 2nd leaf & 29 & 29 & $27^{* *}$ & 51 & $222 * *$ & $1.8 \pm 0.27$ & $7.7 \pm 0.31^{* *}$ \\
\hline & 3rd leaf & 29 & 25 & $29 * *$ & 56 & $230 * *$ & $1.9 \pm 0.19$ & $7.9 \pm 0.24 * *$ \\
\hline & $\begin{array}{l}\text { Light } \\
\text { control }\end{array}$ & 20 & 0 & $0^{* *}$ & 0 & $0 * *$ & 0 & $0^{* *}$ \\
\hline
\end{tabular}

* Observed on July 14.

** Observed on July 23.

Other observations were made on August 9.

buds of the donor leaf. In 27 out of 29 plants, whose second leaf was the donor, and in 25 out of 29 plants, whose third leaf was the donor, the stimulus received by the donor leaf was transmitted to the lateral shoot of the adjacent node causing flower initiation. But when the stem between the two nodes was ringed, the lateral buds failed to initiate flower primordia in so far as they were separated from the treated leaf by ringing, irrespective of the position of the leaves.

Table 1 shows that the number of flower primodia on the third bud in a ringed plant is less than in the control plants. As the buds above the ringed parts begin to die after about 10 days, the observations must be made early before the response manifests itself completely at the growing point. Therefore the number of flower primordia observed is considerably less than could have been expected when the bud would have developed normally.

The experiment shows clearly that the photoperiodic stimulus can be transferred up and down the stem but not across the ringed part in Pharbitis Nil as reported for Xanthium and Perilla $(1,2,6)$.

It is also remarkable that, in control lots, the number of flower buds initiated on the lateral shoot of the second node is far less than that on the shoot of the third node, whichever leaf was exposed to short day. The following facts may be given as a reason for this. The axillary bud of the third node begins to develop 
immediately upon removal of the main axis whereas that of the second node remains dormant or apparently so before the third node is removed. Thus at the time of dark treatment the upper bud predominates over the lower one in its developmental rate and, in addition, the reactability of the former is higher than that of the latter. In the lot in which the second bud was separated from the third by ringing, the former bud produced a relatively large number of flower primordia as compared with that of the non-ringed plant.

Transmission through the incised stem. Plants were deprived of the main axes above the fourth node, all leaves and buds were removed to the third leaf and the fourth bud. One lot of these plants were given several incisions on two opposite flanks of the stems between the third and fourth nodes. Another lot without incisions served as control. Then the plants were exposed to a 21 hour dark period. Flowering responses on the fourth axillary bud are represented in Table 2 (Exp. 1). In the

Table 2. Transmission of photoperiodic stimulus across the incised stem of Pharbitis Nil.

\begin{tabular}{|l|c|c|c|c|c|c|}
\hline Treatment & $\begin{array}{c}\text { Duration of } \\
\text { dark period } \\
\text { in hours }\end{array}$ & $\begin{array}{c}\text { No. of } \\
\text { plants } \\
\text { observed }\end{array}$ & $\begin{array}{c}\text { No. of plants } \\
\text { with flower of flower } \\
\text { primordia }\end{array}$ & $\begin{array}{c}\text { Average number } \\
\text { primordia flower pri- } \\
\text { mordia per plant }\end{array}$ \\
\hline Exp. I* & $\begin{array}{l}\text { Stems were incised } \\
\text { between the 3rd } \\
\text { and 4th node. } \\
\text { No incisions. }\end{array}$ & 21 & 19 & 16 & 83 & $4.4 \pm 0.70$ \\
\hline Exp. II** & $\begin{array}{l}\text { Stems were incised } \\
\text { between the 3rd } \\
\text { and 4th node. } \\
\text { No incisions. }\end{array}$ & 16 & 17 & 20 & 136 & $6.8 \pm 0.72$ \\
\hline
\end{tabular}

* Sown on May 21, treatment started on June 23, dissected on July 14, 1950.

* Sown on September 18, treatment started on October 9, dissected on November 9, 1955.

control lot, all plants, and in the experimental lot, 16 out of 19 plants initiated flower primordia. The number of flower primordia initiated was also less in the experimental plants than in the control plants. Thus, the photoperiodic stimulus can be transferred across the incised stem, though with some difficulty.

In another experiment, quite similar results were obtained (Table 2, Exp. 2). The plants were exposed to a 16 hour dark period, and flowering responses in plants with incised stem were far less than in the control plants.

\section{Discussion and Summary}

From the present experiments, it may be concluded that the transmission of photoperiodic stimulus occurs only through living cells, not through vessels, and that it is somewhat inhibited by incisions made on the opposite flanks of the stem, through which the stimulus is transferred. 
Because of the technical difficulties of the incision experiments we are not sure whether all the conductive strands of the stem had been severed or some of them remained intact. Also the possibility of diffusion of the stimulus through an incised surface can not be excluded, as no device against diffusion was applied. Therefore from this experiment neither the mode of transmission nor the tissue concerned can be with certainty established.

In a plant with two buds the developing bud on the higher node received more stimulus and produced more flower primordia than that on the lower node. Recently, Salisbury reported that an actively growing bud of Xanthium has higher sensitivity to photoperiodic induction than a dormant one, i.e. if actively growing buds are removed during or after induction, the dormant buds, when they become active, remain vegetative (5). This is also the case in Pharbitis Nil. In the present investigation, in plants with two buds the bud on the higher node was activated immediately upon removal of the main axis but that on the lower node was dormant or nearly so, and was forced to develop about 20 days after the photoperiodic treatment.

\section{Literature}

1) Cajlachjan, M. Ch., Compt. Rend. Acad. Sci. USsR, N. s. 18: 607-612 (1943) (Ber. ü. wiss. Bio!. 48: 348). 2)— Bull. Acad. Sci. USSR 5-6: 1947-1979 (1938) (Ber. ü. wiss. Biol. 51: 524-525). 3) Imamura, S. and Takimoto, A., Bot. Mag. Tokyo 68:235-241 (1955). 4) — and Bot. Mag. Tokyo 68: 260-266 (1955). 5) Salisbury, F. B., Plant Physiol. 30: 327-334 (1955). 6) Withrow, A. P. and Withrow, R. B., Bot. Gaz. $104:$ 409-416 (1943).

\section{SHORT COMMUNICATION}

\section{Hideo ToRIYAMA** Preliminary Note on the Migration of a Colloidal Substance in the Motor Tissue of Mimosa pudica*}

\section{鳥山英雄**：オジギッウの運動組織に扣けるコロイド状物質の移動}

\section{Received October 26, 1956}

Leaflets, petioles or whole branches of Mimosa pudica are known to show an appearance of wilt by stimulation. This change in the turgor of the responsible tissue cells is supposed to have a close relationship to the behavior of potassium ions in the tissue, which has been analysed in detail previously.2) The present author was able to observe the translocation of some kind of colloidal substance in the

\footnotetext{
*This report was presented at the annual meeting of the Botanical Society of Japan, held in July, 1956 at Sapporo.

** Biological Section, Tokyo Woman's Christian College. 東京女子大学 生物学教室
} 